УДК 658.153:338.244

DOI: $10.15673 /$ fie.v13i3.2131

Купріна Н.M.

доктор економічних наук, доцент кафедра обліку та аудиту

E-mail:k.natali_@ukr.net

ORCID ID: 0000-0003-4645-545X

Антонюк О.П.

кандидат економічних наук, доцент кафедра обліку та аудиту

E-mail: olegantoni@ukr.net

ORCID ID: 0000-0002-9182-4982
Ступницька Т.M.

кандидат економічних наук, доцент кафедра обліку та аудиту

E-mail: t.stupnitska@gmail.com

ORCID ID: 0000-0002-2517-2795

Величко О.М.

студентка 4 курсу фракультету економіки, бізнесу і контролю Одеська національна академія харчових технологій

вул. Канатна 112, м. Одеса, Україна, 65039

E-mail: velichko20012001@gmail.com

ORCID ID: 0000-0002-8591-878X

\title{
СУЧАСНІ АСПЕКТИ ФІНАНСОВОГО АНАЛІЗУ ОБОРОТНИХ АКТИВІВ ПІДПРИЕМСТВА
}

Ефективне функціонування будь-якого підприємства в сучасних умовах не можливе без ефективного управління його капіталом, який вкладено в його оборотні активи. Оборотний капітал повинен мати достатню швидкість обороту та потребує постійному моніторингу та аналізу, що сприяє ефективному його використанню та управлінню, та потребує проведення якісного його фінансового аналізу.

В статті проведено дослідження теоретичних та практичних аспектів фрінансового аналізу оборотних активів в сучасних умовах функціонування підприємств. Показано, що детальний аналіз важливих елементів оборотних активів дозволить проводити постійний моніторинг за їх станом, структурою та динамікою, що буде спряти ефективному управлінню ними та перешкоджати відволікання оборотного капіталу з обороту підприємства та процесу нормального фінансування його діяльності. Тому важливими етапами аналізу оборотних активів, на нашу думку, є й розрахунок в динаміці фінансового циклу підприємства й фінансовий аналіз відносних показників, які характеризують фінансову стійкість підприємства та ліквідність його балансу, що має особливе значення для ефективного функціонування підприємства, залучення інвестицій та розвитку діяльності, та для розрахунку яких використовують або показники оборотних активів та власних оборотних коштів (активів).

Ключові слова: оборотні активи, оборотний капітал, елементи оборотних активів, підприємство, фрінансовий аналіз, етапи фрінансового аналізу, ефективність використання.

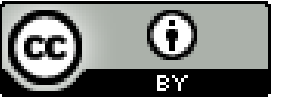

This work is licensed under a Creative Commons Attribution 4.0 International License http://creativecommons.org/licenses/by/4.0/
Постановка проблеми та її зв'язок з важливими науковими та практичними завданнями. Ефективне функціонування будь-якого підприємства в сучасних умовах не можливе без ефективного управління його капіталом, який вкладено в його оборотні та необоротні активи. Оборотний капітал, якій вкладено в такі елементи оборотних активів, як запаси, дебіторську заборгованість, поточні фінансові інвестиції, витрати майбутніх періодів, інші оборотні активи та самі грошові кошти, повинен мати достатню швидкість обороту та потребує постійному моніторингу та аналізу, що сприяє ефективному його використанню та управлінню. Як показало попереднє наше дослідження [1], оборотний капітал підприємства $є$ необхідною умовою та джерелом фінансування діяльності підприємства та потребує вибору сучасних інструментів, в системі управління підприємством, таких як аудит, управлінський облік та фінансовий аналіз.

Тому проведення саме якісного фінансового аналізу, базується на системному та комплексному підході, є першим етапом в системі управління оборотним капіталом підприємства, та потребує вивчення досліджень учених та практичних аспектів його застосування в сучасних умовах.

Аналіз останніх досліджень і публікацій. Дослідження проведення фінансового аналізу оборотних активів та управління оборотним капіталом підприємства, який вкладено в їх елементи, досліджувались українськими та іноземними вченими, такими як Антонюк О., Барабаш Н., Баумоль У., Білик М., Бланк І., Бутинць Ф., Брігхейм Ю., Буркинський Б., Бурсук Г., Бутенко А., Горовий Д., Золотарьов А., Кірєйцев Г., Коновалова О., Крамаренко Г., Майєрс С., Мартін Д., Мертон Р., Матвіюк А., Міллер М., Мец В., Мних Є., Нашкерська Г.В., Невмержицька Н., Орр Д., Осипов П., Павленко О., Павловська О., Притуляк Н., Поддерегін А, Савченко А., Стоянова О., Тарасенко О., Терещенко О., Томкінс Д., Шеремет В., Фролов В., Цал-Цалко Ю. та ін., але 
потребують додаткових досліджень з метою ефективного використання оборотних активів в системі управління підприємством.

Формулювання цілей дослідження. Метою даної статті є дослідження теоретичних та практичних аспектів проведення фінансового аналізу оборотних активів підприємства, в який вкладено оборотний капітал, на підставі системного та комплексного підходу та з метою забезпечення ефективності його функціонування та в системі управління підприємства.

Виклад основних результатів та їх обгрун- тування. Дослідження показало, що в публікаціях вчених та практичних джерелах існує безліч підходів до виділення етапів проведення аналізу оборотних активів, так як кожний $з$ них виділяє, зі своєї точки зору, ключові етапи такого аналізу. Деякі з них є спільними для більшості досліджень вчених, як наприклад, аналіз складу, структури та динаміки активів, оборотних активів та їх елементів, джерел їх фінансування, оборотності оборотних активів та їх елементів, рентабельності оборотних активів та іï факторного аналізу (табл. 1).

Таблиця 1

Етапи проведення аналізу оборотних активів підприємства в наукових джерелах*

\begin{tabular}{|c|c|c|c|c|c|c|c|c|c|c|}
\hline \multirow[b]{2}{*}{$\begin{array}{l}\text { Етапи } \\
\text { аналізу }\end{array}$} & \multicolumn{10}{|c|}{ Автор, джерело } \\
\hline & 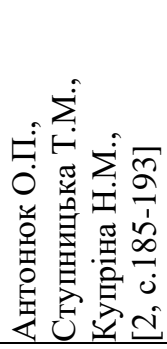 & 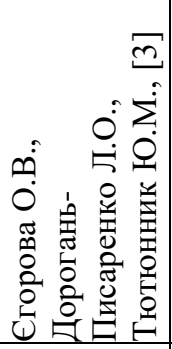 & 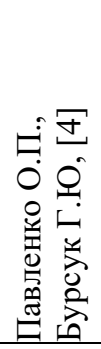 & 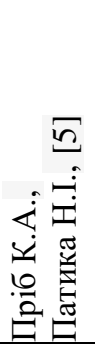 & 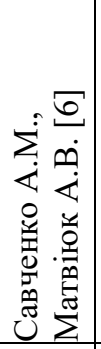 & 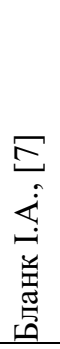 & 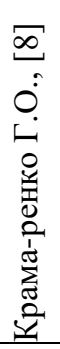 & 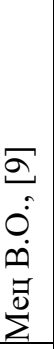 & 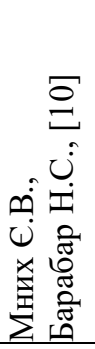 & 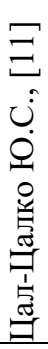 \\
\hline $\begin{array}{l}\text { Аналіз складу, структури та ди- } \\
\text { наміки активів }\end{array}$ & + & + & + & + & - & + & - & - & - & - \\
\hline $\begin{array}{l}\text { Аналіз складу, структури та ди- } \\
\text { наміки оборотних активів }\end{array}$ & + & + & + & + & - & + & + & + & + & + \\
\hline $\begin{array}{l}\text { Аналіз структури розміщення } \\
\text { оборотного капіталу }\end{array}$ & + & - & - & - & - & - & - & - & - & - \\
\hline $\begin{array}{l}\text { Аналіз складу, структури та ди- } \\
\text { наміки елементів оборотних ак- } \\
\text { тивів, в т.ч.: } \\
\text {-запасів; } \\
\text {-дебіторської заборгованості; } \\
\text {-грошових коштів }\end{array}$ & $\begin{array}{l}+ \\
+ \\
+ \\
\end{array}$ & $\begin{array}{l}+ \\
+ \\
+\end{array}$ & $\begin{array}{l}+ \\
+ \\
+ \\
\end{array}$ & $\begin{array}{l}+ \\
+ \\
+ \\
\end{array}$ & $\begin{array}{l}+ \\
+ \\
+ \\
\end{array}$ & $\begin{array}{l}+ \\
+ \\
+ \\
\end{array}$ & $\begin{array}{l}+ \\
+ \\
+ \\
\end{array}$ & $\begin{array}{l}+ \\
+ \\
+ \\
\end{array}$ & $\begin{array}{l}+ \\
+ \\
+ \\
\end{array}$ & $\begin{array}{l}+ \\
+ \\
+ \\
\end{array}$ \\
\hline $\begin{array}{l}\text { Аналіз використання оборотних } \\
\text { коштів }\end{array}$ & + & + & - & - & - & + & + & + & + & + \\
\hline Аналіз фінансової стабільності & + & - & - & - & - & - & - & - & - & - \\
\hline $\begin{array}{l}\text { Аналіз відносних показників лік- } \\
\text { відності балансу }\end{array}$ & + & - & - & - & - & + & + & + & + & + \\
\hline $\begin{array}{l}\text { Розрахунок коефіцієнтів - від- } \\
\text { ношень між окремим видами } \\
\text { оборотних активів та джерелами } \\
\text { їх формування }\end{array}$ & - & + & - & - & - & - & - & - & - & - \\
\hline $\begin{array}{l}\text { Розрахунок та оцінка показників } \\
\text { ефективності використання обо- } \\
\text { ротних активів }\end{array}$ & + & + & + & + & + & - & - & - & - & - \\
\hline $\begin{array}{l}\text { Проведення факторного аналізу } \\
\text { показників ділової активності }\end{array}$ & - & - & + & - & - & - & - & - & - & - \\
\hline $\begin{array}{l}\text { Визначення частки вартості обо- } \\
\text { ротних активів об’єкта дослі- } \\
\text { джень у вартості оборотних ак- } \\
\text { тивів галузі, регіону, країни в } \\
\text { цілому }\end{array}$ & - & - & + & - & - & - & - & - & - & - \\
\hline $\begin{array}{l}\text { Визначення джерел фінансування } \\
\text { оборотних активів - динаміка їх } \\
\text { суми та питомої ваги у загальній } \\
\text { сумі фінансових засобів }\end{array}$ & + & - & - & + & + & + & + & + & + & + \\
\hline $\begin{array}{l}\text { Визначення рентабельності та } \\
\text { вплив на неї факторів }\end{array}$ & + & - & - & - & - & + & + & + & + & + \\
\hline
\end{tabular}

*Складено авторами на підставі джерел [2-11] 
На думку I.О. Бланка [7] аналіз оборотних активів повинен починатися саме з розгляду динаміки загального об'єму оборотних активів, які використовуються - темпи зміни їх середньої суми зіставляються 3 темпами зміни обсягів реалізації продукції (робіт, послуг) та з середньою сумою всіх активів. Але, на думку Ю.С. Цал-Цалко [11], В.О. Меца [9], С.В. Мниха, Н.С. Барабаша [10], Г.О. Крамаренка [8], Савченко А.М., Матвіюка А.В. [6] аналіз оборотних активів необхідно починати 3 оцінки динаміки основних видів оборотних активів та оцінки їх ліквідності. Лише деякі науковці [4] - приділяють увагу аналізу причин зміни оборотних активів, тобто факторному аналізу зміни в оборотних активах. Необхідність його проведення, на нашу думку, полягає в тому, що всі явища та процеси господарської діяльності підприємства знаходяться у взаємозв'язку, а будь-який результат діяльності залежить від різноманітних факторів. Тому важливим для управління активами, в які вкладено капітал підприємства, є питання вивчення, вимірювання, аналіз впливу факторів на величину показників оборотних активів.

Наше попереднє дослідження показало [1], що одним 3 важливих етапів аналізу оборотних активів, $є$ аналіз складу, структури та динаміки його таких елементів, як грошові кошти, запаси та дебіторська заборгованість, що проведено нами на підставі даних фінансової звітності підприємства АПК Одеської області за 3 роки (табл. 2-4).

Таблиця 2

Аналіз складу, структури та динаміки грошових коштів*

\begin{tabular}{|c|c|c|c|c|c|c|c|c|c|c|c|}
\hline \multirow{3}{*}{ Показники } & \multirow{3}{*}{$\begin{array}{c}\text { Код } \\
\text { рядка }\end{array}$} & \multicolumn{3}{|c|}{$\begin{array}{c}\text { Абсолютна } \\
\text { величина }\end{array}$} & \multicolumn{3}{|c|}{$\begin{array}{r}\text { Питома } \\
\text { вага, \% }\end{array}$} & \multicolumn{4}{|c|}{ Відхилення } \\
\hline & & \multirow{2}{*}{ 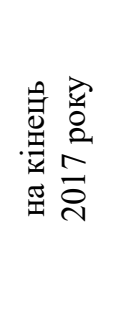 } & \multirow{2}{*}{ 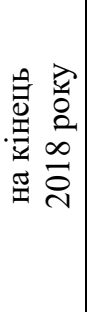 } & \multirow{2}{*}{ 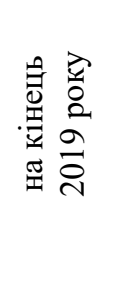 } & \multirow{2}{*}{ 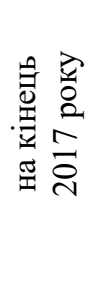 } & \multirow{2}{*}{ 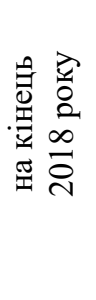 } & \multirow{2}{*}{ 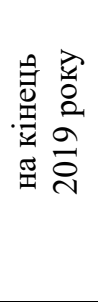 } & \multicolumn{2}{|c|}{ абсолютне } & \multicolumn{2}{|c|}{ питомої ваги } \\
\hline & & & & & & & & $\begin{array}{c}2018 \\
\text { від } \\
2017\end{array}$ & $\begin{array}{c}2019 \\
\text { від } \\
2018\end{array}$ & $\begin{array}{c}2018 \\
\text { від } \\
2017\end{array}$ & $\begin{array}{c}2019 \\
\text { від } \\
2018\end{array}$ \\
\hline $\begin{array}{l}\text { Грошові } \\
\text { кошти, тис. } \\
\text { грн., } \\
\text { в тому числі: }\end{array}$ & $\begin{array}{l}\text { Ф№5 } \\
\text { Р.690 }\end{array}$ & 11966 & 4613 & 12631 & 100 & 100 & 100 & -7353 & 8018 & $\mathrm{x}$ & $\mathrm{x}$ \\
\hline - в касі & $\begin{array}{l}\text { Ф№5 } \\
\text { P.640 }\end{array}$ & 41 & 54 & 24 & 0,34 & 1,17 & 0,19 & 13 & -30 & 0,83 & $-0,98$ \\
\hline $\begin{array}{l}\text { - на } \\
\text { поточному } \\
\text { рахунку в } \\
\text { банку } \\
\end{array}$ & $\begin{array}{l}\text { Ф№5 } \\
\text { Р.650 }\end{array}$ & 11925 & 4559 & 12607 & 99,66 & 98,83 & 99,81 & -7366 & 8048 & $-0,83$ & 0,98 \\
\hline $\begin{array}{l}\text { - інших } \\
\text { рахунках в } \\
\text { банку } \\
\end{array}$ & $\begin{array}{l}\text { Ф№5 } \\
\text { Р.660 }\end{array}$ & - & - & - & - & - & - & - & - & - & - \\
\hline $\begin{array}{l}\text { - грошові } \\
\text { кошти в } \\
\text { дорозі } \\
\end{array}$ & $\begin{array}{l}\text { Ф№5 } \\
\text { Р.670 }\end{array}$ & - & - & - & - & - & - & - & - & - & - \\
\hline $\begin{array}{l}\text { - еквіваленти } \\
\text { грошових } \\
\text { коштів }\end{array}$ & $\begin{array}{l}\text { Ф№5 } \\
\text { p.680 }\end{array}$ & - & - & - & - & - & - & - & - & - & - \\
\hline
\end{tabular}

*Складено авторами на підставі даних фінансової звітності підприємства АПК

Так, результати розрахунків у табл. 2 свідчать, що грошові кошти на кінець 2018 року порівняно з 2017 роком зменшились на 7353 тис. грн. або на 61,45 \%. Це відбулось за рахунок збільшення коштів в касі на 13 тис.грн., або на $31,7 \%$, i зменшення коштів на поточному рахунку в банку на 7366 тис.грн., або на 61,77 \%. В структурі грошових коштів на кінець 2017 року найбільшу питому вагу займають кошти на поточному рахунку - 99,66\%, питома вага коштів в касі склала 0,34\%. На кінець
2018 року відбулись наступні зміни в структурі запасів: збільшилась питома вага кошти на поточному рахунку на $0,83 \%$ п.; зменшилась питома вага коштів в касі на $0,83 \%$ пункти.

У 2019 році в порівнянні з 2018 роком у складі грошових коштів відбулись такі зміни: на кінець 2019 року обсяг грошових коштів збільшився на 8018 тис. грн., або на 173,8\%. Це відбулося за рахунок збільшення коштів на поточному рахунку в банку на 8048 тис. грн., або на 176,5\%, і зменшення коштів 
в касі на 30 тис. грн. або на 55,55\%. В структурі грошових коштів на кінець 2018 року: найбільшу питому вагу займали кошти на поточному рахунку в банку $98,83 \%$, питома вага коштів в касі склала $-1,17 \%$.
Структура грошових коштів на кінець 2019 року не дуже змінилась: збільшилась частка коштів на поточному рахунку на $0,98 \%$ пункти та зменшилась частка коштів в касі на 0,98\% пункти.

Таблиця 4

Аналіз складу, структури та динаміки запасів*

\begin{tabular}{|c|c|c|c|c|c|c|c|c|c|c|c|}
\hline \multirow{3}{*}{ Показники } & \multirow{3}{*}{$\begin{array}{c}\text { Код } \\
\text { рядка }\end{array}$} & \multicolumn{3}{|c|}{$\begin{array}{c}\text { Абсолютна } \\
\text { величина }\end{array}$} & \multicolumn{3}{|c|}{$\begin{array}{r}\text { Питома } \\
\text { вага, \% }\end{array}$} & \multicolumn{4}{|c|}{ Відхилення } \\
\hline & & \multirow{2}{*}{ 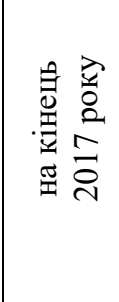 } & \multirow{2}{*}{ 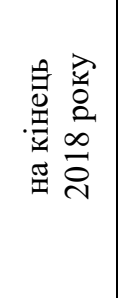 } & \multirow{2}{*}{ 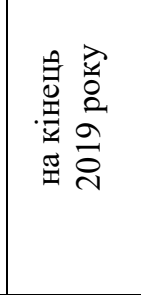 } & \multirow{2}{*}{ 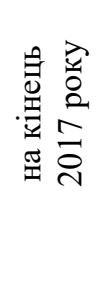 } & \multirow{2}{*}{ 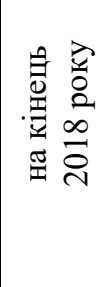 } & \multirow{2}{*}{ 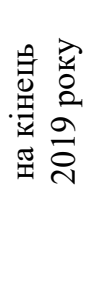 } & \multicolumn{2}{|c|}{ абсолютне } & \multicolumn{2}{|c|}{ питомої ваги } \\
\hline & & & & & & & & $\begin{array}{c}2018 \\
\text { від } \\
2017\end{array}$ & $\begin{array}{c}2019 \\
\text { від } \\
2018\end{array}$ & $\begin{array}{c}2018 \\
\text { від } \\
2017\end{array}$ & $\begin{array}{c}2019 \\
\text { від } \\
2018\end{array}$ \\
\hline $\begin{array}{l}\text { Запаси всього, } \\
\text { в тому числі: }\end{array}$ & $\begin{array}{l}\text { Ф№5 } \\
\text { P.920 }\end{array}$ & 101411 & 116987 & 119132 & 100 & 100 & 100 & 15576 & 2145 & $\mathrm{x}$ & $\mathrm{x}$ \\
\hline $\begin{array}{l}\text { 1.1.Виробничі } \\
\text { запаси, } \\
\text { В т.ч.: }\end{array}$ & Ф№5 & 21887 & 24849 & 23594 & 21,58 & 21,24 & 19,80 & 2962 & -1255 & $-0,34$ & $-1,44$ \\
\hline $\begin{array}{l}\text {-сировина i } \\
\text { матеріали }\end{array}$ & $\begin{array}{l}\text { Ф№5 } \\
\text { P.800 }\end{array}$ & 48 & 87 & 122 & 0,05 & 0,07 & 0,10 & 39 & 35 & 0,02 & 0,03 \\
\hline $\begin{array}{l}\text {-купівельні } \\
\text { напівфабрикати }\end{array}$ & $\begin{array}{l}\text { Ф№5 } \\
\text { P.810 }\end{array}$ & - & - & - & - & - & - & - & - & - & - \\
\hline -паливо & $\begin{array}{l}\text { Ф№5 } \\
\text { P.820 }\end{array}$ & 1677 & 2422 & 2500 & 1,66 & 2,07 & 2,1 & 745 & 78 & 0,41 & 0,03 \\
\hline $\begin{array}{l}\text {-тара і тарні } \\
\text { матеріали }\end{array}$ & $\begin{array}{l}\text { Ф№5 } \\
\text { P.830 }\end{array}$ & 49 & 49 & 171 & 0,05 & 0,04 & 0,14 & - & 122 & $-0,01$ & 0,1 \\
\hline $\begin{array}{l}\text {-будівельні } \\
\text { матеріали }\end{array}$ & $\begin{array}{l}\text { Ф№5 } \\
\text { P.840 }\end{array}$ & 521 & 237 & 285 & 0,51 & 0,2 & 0,24 & -284 & 48 & $-0,31$ & 0,04 \\
\hline $\begin{array}{l}\text {-запасні } \\
\text { частини }\end{array}$ & $\begin{array}{l}\text { Ф№5 } \\
\text { P.850 }\end{array}$ & 669 & 916 & 768 & 0,66 & 0,78 & 0,64 & 247 & -148 & 0,12 & $-0,14$ \\
\hline $\begin{array}{l}\text {-матеріали } \\
\text { сільськогоспо- } \\
\text { дарського } \\
\text { призначення }\end{array}$ & $\begin{array}{l}\text { Ф№5 } \\
\text { P.860 }\end{array}$ & 18198 & 20293 & 18929 & 17,94 & 17,34 & 15,89 & 2095 & -1364 & $-0,6$ & $-1,45$ \\
\hline $\begin{array}{l}\text {-малоцінні та } \\
\text { швидкозношу- } \\
\text { ванні предмети }\end{array}$ & $\begin{array}{l}\text { Ф№5 } \\
\text { P.880 }\end{array}$ & 725 & 845 & 819 & 0,71 & 0,72 & 0,69 & 120 & -26 & 0,01 & $-0,03$ \\
\hline $\begin{array}{l}\text { 1.2.Поточні } \\
\text { біологічні } \\
\text { активи }\end{array}$ & $\begin{array}{l}\text { Ф№5 } \\
\text { P.870 }\end{array}$ & 6286 & 4024 & 5068 & 6,2 & 3,44 & 4,25 & -2262 & 1044 & $-2,76$ & 0,81 \\
\hline $\begin{array}{l}\text { 1.3.Незаверше- } \\
\text { не виробництво }\end{array}$ & $\begin{array}{l}\text { Ф№5 } \\
\text { P.890 }\end{array}$ & 21661 & 21368 & 17963 & 21,36 & 18,27 & 15,08 & -293 & -3405 & $-3,09$ & $-3,19$ \\
\hline $\begin{array}{l}\text { 1.4.Готова } \\
\text { продукція }\end{array}$ & $\begin{array}{l}\text { Ф№5 } \\
\text { P.900 }\end{array}$ & 51576 & 66745 & 72507 & 50,86 & 57,05 & 60,86 & 15169 & 5762 & 6,19 & 3,81 \\
\hline 1.5.Товари & $\begin{array}{l}\text { Ф№5 } \\
\text { P.910 }\end{array}$ & 1 & 1 & - & 0 & 0 & - & 0 & -1 & - & - \\
\hline
\end{tabular}

*Складено авторами на підставі даних фінансової звітності підприємства АПК

Дані табл. 3 показують, що запаси на кінець 2018 року порівняно з 2017 роком збільшились на 15 576 тис. грн. або на 15,36 \%. Це відбулось за рахунок збільшення:готової продукції на 15169 тис.грн., або на 29,41\%, виробничих запасів на 2962 тис. грн. або на $13,53 \%$ (за рахунок збільшення: матеріалів сільськогосподарського призначення - на 2095 тис.грн або на 11,51\%, палива - на 745 тис.грн., або на $44,42 \%$, запасних частин - на 247 тис.грн. або на $36,92 \%$, малоцінних та швидкозношуванних предметів - на120 тис.грн., або на 16,55\%, і зменшення будівельних матеріалів на 284 тис.грн., 
або на 54,51\%), а також відбулось зменшення поточних біологічних активів на 2262 тис. грн. або на $35,98 \%$, і незавершеного виробництва на 293 тис.грн., або на $1,35 \%$.

В структурі запасів на кінець 2017 року найбільшу питому вагу займає готова продукція $50,86 \%$, питома вага виробничих запасів склала $21,58 \%$, незавершеного виробництва - 21,36\%, поточних біологічних активів - 6,2\%. На кінець 2018 року відбулись наступні зміни в структурі запасів: збільшилась питома вага готової продукції на 6,19% п.; зменшилась питома вага виробничих запасів на 0,34\% пункти, незавершеного виробництва - на $3,09 \%$ п., поточних біологічних активів - на 2,76\% пункти.

У 2019 році в порівнянні з 2018 роком запаси збільшились на 2145 тис. грн., або на 1,83\%. Це відбулось за рахунок збільшення:готової продукції на
5762 тис.грн., або на 8,63\%, поточних біологічних активів на 1044 тис. грн.. або на 16,61\%, а також відбулось зменшення виробничих запасів на 1255 тис. грн. або на 5,05\% (за рахунок зменшення: матеріалів сільськогосподарського призначення - на 1364 тис.грн або на $6,72 \%$, запасних частин - на 148 тис.грн. або на 16,16\%, малоцінних та швидкозношуванних предметів - на 26 тис.грн., або на 3,08\%, і збільшення будівельних матеріалів на 48 тис.грн., або на 20,25\%, палива - на 78 тис.грн., або на $3,22 \%$ ), і незавершеного виробництва на 3405 тис.грн., або на 15,94\%. На кінець 2019 року відбулись наступні зміни в структурі запасів: збільшилась питома вага готової продукції на 3,81 \% п. і поточних біологічних активів - на 0,81 \% пункти; зменшилась питома вага незавершеного виробництва - на 3,19\% п., виробничих запасів - на 1,44 \% пункти.

Таблиця 4

\section{Аналіз складу, структури та динаміки дебіторської заборгованості*}

\begin{tabular}{|c|c|c|c|c|c|c|c|c|c|c|c|}
\hline \multirow{3}{*}{ Показники } & \multirow{3}{*}{$\begin{array}{c}\text { Код } \\
\text { рядка }\end{array}$} & \multicolumn{3}{|c|}{$\begin{array}{c}\text { Абсолютна } \\
\text { величина }\end{array}$} & \multicolumn{3}{|c|}{$\begin{array}{l}\text { Питома } \\
\text { вага, \% }\end{array}$} & \multicolumn{4}{|c|}{ Відхилення } \\
\hline & & \multirow{2}{*}{ 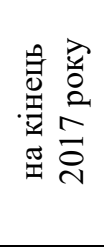 } & \multirow{2}{*}{ 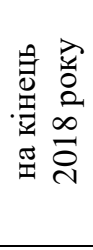 } & \multirow{2}{*}{ 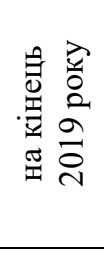 } & \multirow{2}{*}{ 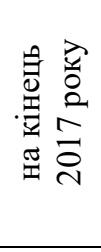 } & \multirow{2}{*}{ 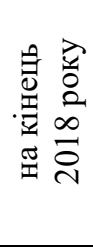 } & \multirow{2}{*}{ 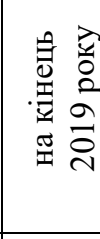 } & \multicolumn{2}{|c|}{ абсолютне } & \multicolumn{2}{|c|}{ питомої ваги } \\
\hline & & & & & & & & $\begin{array}{c}2018 \\
\text { від } \\
2017 \\
\end{array}$ & $\begin{array}{c}2019 \\
\text { від } \\
2018 \\
\end{array}$ & $\begin{array}{c}2018 \\
\text { від } \\
2017 \\
\end{array}$ & $\begin{array}{c}2019 \\
\text { від } \\
2018 \\
\end{array}$ \\
\hline $\begin{array}{l}\text { Дебіторська } \\
\text { заборгованість } \\
\text { всього, } \\
\text { в тому числі: }\end{array}$ & $\begin{array}{c}1125 \div \\
1155\end{array}$ & 5253 & 4683 & 4258 & 100 & 100 & 100 & -570 & -425 & $\mathrm{x}$ & $\mathrm{x}$ \\
\hline $\begin{array}{l}\text { 1.1. Дебіторська } \\
\text { заборгованість за } \\
\text { товари, роботи, } \\
\text { послуги* }\end{array}$ & $\begin{array}{l}1120 \\
1125\end{array}$ & 1240 & 4194 & 270 & 23,6 & 89,6 & 6,34 & 2954 & -3924 & 65,9 & $-83,26$ \\
\hline $\begin{array}{l}\text { 1.2. Дебіторська } \\
\text { заборгованість за } \\
\text { розрахунками : }\end{array}$ & $\begin{array}{c}1130 \div \\
1145\end{array}$ & 3319 & 189 & 2190 & 63,2 & 4,04 & 51,43 & -3130 & 2001 & $-59,1$ & 47,39 \\
\hline $\begin{array}{l}\text { - за виданими } \\
\text { авансами }\end{array}$ & 1130 & 3283 & 185 & 2190 & 62,5 & 3,9 & 51,43 & -3098 & 2005 & $-58,5$ & 47,53 \\
\hline - 3 бюджетом, & 1135 & - & - & - & - & - & - & - & - & - & - \\
\hline $\begin{array}{l}\text { - в тому числі } 3 \\
\text { податку на } \\
\text { прибуток }\end{array}$ & 1136 & - & - & - & - & - & - & - & - & - & - \\
\hline $\begin{array}{l}\text { - } 3 \text { нарахованих } \\
\text { доходів }\end{array}$ & 1140 & - & - & - & - & - & - & - & - & - & - \\
\hline $\begin{array}{l}\text { - із внутрішніх } \\
\text { розрахунків }\end{array}$ & 1145 & 36 & 4 & - & 1,1 & 2,1 & - & -32 & -4 & 1,03 & $-2,1$ \\
\hline $\begin{array}{l}\text { 1.3. Інша } \\
\text { поточна } \\
\text { дебіторська } \\
\text { заборгованість }\end{array}$ & 1155 & 694 & 300 & 1798 & 13,2 & 6,4 & 42,23 & -394 & 1498 & $-6,8$ & 35,83 \\
\hline
\end{tabular}

*Складено авторами на підставі даних фінансової звітності підприємства АПК

3 табл. 4 видно, що дебіторська заборгованість на кінець 2018 року порівняно з 2017 роком зменшилась на 570 тис. грн. або на 10,9\%. Це відбулось за рахунок зменшення: дебіторської 
заборгованості за розрахунками на 3130 тис. грн.. або на 94,3\% (за рахунок зменшення: розрахунків за виданими авансами - на 3098 тис.грн або на 94,4\%, розрахунки із внутрішніх розрахунків на 32 тис.грн. або на 88,9\%) і іншої поточної дебіторської заборгованості - на 394 тис.грн або на 56,8\%, а також відбулось збільшення дебіторської заборгованість за товари, роботи, послуги на 2954 тис. грн.. або на $238,23 \%$.

В структурі дебіторської заборгованості на кінець 2017 року найбільшу питому вагу займає заборгованість за розрахунками - 63,2\%, питома вага заборгованості за товари, роботи, послуги склала 23,6\%, іншої заборгованості - 13,2\%. На кінець 2018 року відбулись наступні зміни в структурі дебіторської заборгованості: збільшилась питома вага заборгованості за товари, роботи послуги на 66 \% п. відповідно; зменшилась питома вага заборгованості за розрахунками на 59,2\%. пункти та іншої заборгованості - на $6,8 \%$. У 2019 році в порівнянні 3 2018 роком дебіторська заборгованість на кінець 2019 року зменшилась на 425 тис. грн., або на 9,08\%. Це відбулось за рахунок збільшення: дебіторської заборгованості за розрахунками на 2001 тис. грн.. або на $1058,7 \%$ (за рахунок збільшення розрахунків за виданими авансами - на 2005 тис.грн або на 1083,8 \%

і зменшення розрахунків із внутрішніх розрахунків на 4 тис.грн. або на 100 \%) і іншої поточної дебіторської заборгованості - на 1498 тис.грн або на 499,33 \%, а також відбулось зменшення дебіторської заборгованість за товари, роботи, послуги на 3924 тис. грн. або на 93,56\%.

На кінець 2019 року відбулись наступні зміни в структурі дебіторської заборгованості: зменшилась питома вага заборгованості за товари, роботи послуги на 83,3 \% п. відповідно; збільшилась питома вага заборгованості за розрахунками на 47,4\% п. пункти та іншої заборгованості - на $35,83 \%$ п.

Такий детальний аналіз важливих елементів оборотних активів дозволить проводити постійний моніторинг за їх станом, структурою та динамікою, що буде спряти ефективному управлінню ними та перешкоджати відволікання оборотного капіталу 3 обороту підприємства та процесу нормального фінансування його діяльності. Тому важливим етапом аналізу оборотних активів, на нашу думку, є й розрахунок в динаміці фінансового циклу підприємства, якій досліджувався вченими (табл. 5) та має важливе значення в практичної діяльності підприємства.

Таблиця 5

Особливості розрахунку фінансового циклу підприємства в наукових джерелах ,**

\begin{tabular}{|c|c|c|c|c|c|}
\hline \multirow[b]{2}{*}{ Показник } & \multicolumn{5}{|c|}{ Автор, джерело } \\
\hline & $\begin{array}{c}\text { Сгорова О.В., } \\
\text { Дорогань- } \\
\text { Писаренко Л.О., } \\
\text { Тютюнник .М., [3] }\end{array}$ & $\begin{array}{c}\text { Пріб К.А., } \\
\text { Патика H.I., [5] }\end{array}$ & Бланк I.A., [7] & Мец В.О., [9] & $\begin{array}{c}\text { Мних С.В., } \\
\text { Ференц І.Д., [10] }\end{array}$ \\
\hline $\begin{array}{l}\text { Тривалість фі- } \\
\text { нансового циклу } \\
\text { підприємства } \\
\text { (розрахунок за } \\
\text { формулою) }\end{array}$ & $\begin{array}{l}\text { ТФЦ=ТОЦ - } \\
- \text { ПО(КЗ) }\end{array}$ & $\begin{array}{l}\text { ТФЦ=ТОЦ - } \\
- \text { ПО(КЗ) }\end{array}$ & $\begin{array}{c}\text { ТФЦ=ТОЦ+ } \\
+П О(Д 3)- \\
-\Pi О(\text { К3 })\end{array}$ & $\begin{array}{l}\text { ТФЦ=ТОЦ - } \\
- \text { ПО(КЗ) }\end{array}$ & $\begin{array}{c}\text { ТФЦ=ТОЦ - } \\
- \text {-ПО(КЗ) }\end{array}$ \\
\hline
\end{tabular}

*Складено авторами на підставі джерел [3,5,7,9,10];

** де, ТФЦ - тривалість фінансового циклу в днях;

ТОЦ - тривалість операційного циклу в днях;

ПО(ДЗ) - середній період обороту поточної дебіторської заборгованості, в днях;

ПО(КЗ) - середній період обороту поточної кредиторської заборгованості, в днях.

Наше дослідження показало [12, с. 46-47], що для визначення обороту грошових коштів, інвестованих в оборотний капітал, починаючи 3 моменту погашення кредиторської заборгованості за отримані виробничі запаси, і закінчуючи інкасацією дебіторської заборгованості за поставлену готову продукцію, необхідно визначати фінансовий цикл підприємства [13, с. 307], тобто тривалість фінансового циклу (циклу грошового обігу) підприємства (ТФЦ), якій не можливо розрахувати без показників, які характеризують ефективність використання окремих елементів оборотних активів:

$$
\begin{aligned}
& \text { ТФЦ = ТВЦ + ПОдз - Покз, } \\
& \text { ТВЦ = ПОсм + ПОнзв + ПОгп , }
\end{aligned}
$$

де ТВЦ - тривалість виробничого циклу підприємства (запасів); ПОдз - період обороту дебітор- ської заборгованості; ПОкз - період обороту кредиторської заборгованості; ПОсм - період обороту сировини, матеріалів і інших виробничих запасів; ПОнзв - період обороту незавершеного виробництва; ПОгп - період обороту готової продукції.

Ще одним 3 важливих етапів аналізу оборотних автивів, що має особливе значення для ефективного функціонування підприємства, залучення інвестицій та розвитку діяльності, на нашу думку, є фінансовий аналіз відносних показників, які характеризують фінансову стійкість підприємства та ліквідність його балансу, та для розрахунку яких використовують або показники оборотних активів та власних оборотних коштів (активів), або їх елементів (табл. 6-7), що розраховано нами на підставі даних підприємства АПК Одеської області. 
Таблиця 6

Аналіз фінансової стійкості підприсмства за окремими частковими показниками*

\begin{tabular}{|l|c|c|c|c|c|}
\hline \multicolumn{1}{|c|}{ Показники } & $\begin{array}{c}\text { Алгоритм } \\
\text { розрахунку } \\
\text { за кодом } \\
\text { рядка }\end{array}$ & $\begin{array}{c}\text { На кінець } \\
2017 \text { року }\end{array}$ & $\begin{array}{c}\text { На кінець } \\
2018 \text { року }\end{array}$ & $\begin{array}{c}\text { На кінець } \\
2019 \text { року }\end{array}$ & $\begin{array}{c}\text { Нормативне } \\
\text { значення }\end{array}$ \\
\hline $\begin{array}{l}\text { 1.Наявність власних } \\
\text { оборотних коштів (активів) } \\
\text { (ОКвл) }\end{array}$ & $1495-1095$ & 117542 & 114278 & 105417 & збільшення \\
\hline $\begin{array}{l}\text { 2.Коефіцієнт маневреності } \\
\text { власного капіталу (Кман) }\end{array}$ & $\begin{array}{c}1495-1095 / \\
1495\end{array}$ & 0,7 & 0,6 & 0,57 & $0,4 \ldots 0,6$ \\
\hline $\begin{array}{l}\text { З. Коефіцієнт забезпеченості } \\
\text { оборотного капіталу } \\
\begin{array}{l}\text { власними оборотними } \\
\text { коштами (активами) (Кз) }\end{array}\end{array} \begin{array}{c}1495-1095 / \\
1195+1200\end{array}$ & 1,0 & 0,9 & 0,77 & 0,1 \\
\hline
\end{tabular}

*Складено авторами на підставі даних фінансової звітності підприємства АПК

Дані розрахунків, які наведені в табл.6, показують, що фінансова ситуація на підприємстві на кінець 2017 року $є$ абсолютно стійкою, тому що власних оборотних коштів (активів) достатньо для покриття запасів, що позитивно характеризує діяльність підприємства в цей період. На кінець 2018 і 2019 років ситуація на підприємстві змінилась на не стійку, тому що джерел що послаб фінансову напругу не вистачає на покриття нестачі загальної величини джерел формування запасів і характеризує діяльність підприємства негативно. Підприємство має власні оборотні кошти (активи), величина яких зменшується на кінець 2018 року - на 3264 тис.грн, а на кінець
2019 року ще на 8861 тис.грн. Це викликало зменшення значення коефіцієнта маневреності власного капіталу, хоча поки що його величина знаходиться в межах норми, що позитивно характеризує діяльність підприємства. Значення коефіцієнта забезпеченості оборотного капіталу власними оборотними коштами (активами) має тенденцію до зменшення впродовж трьох років. Таким чином, аналіз показників фінансової стійкості підприємства дозволяє зробити висновок про недостатньо ефективне вкладення грошових коштів в діяльність підприємства та зниження фінансову стабільності функціонування підприємства на ринку.

Таблиця 7

Аналіз ліквідності підприємства за відносними показниками*

\begin{tabular}{|c|c|c|c|c|c|c|c|}
\hline \multirow[b]{2}{*}{$\begin{array}{c}\text { Коефіцієнти } \\
\text { ліквідності } \\
\text { підприємства }\end{array}$} & \multirow{2}{*}{$\begin{array}{c}\text { Алгоритм } \\
\text { розрахунку } \\
\text { за кодом } \\
\text { рядка }\end{array}$} & \multirow[b]{2}{*}{ Норма } & \multicolumn{3}{|c|}{ Розрахункові значення } & \multicolumn{2}{|c|}{ Відхилення } \\
\hline & & & $\begin{array}{l}\text { На кінець } \\
2017 \text { року }\end{array}$ & $\begin{array}{l}\text { На кінець } \\
2018 \text { року }\end{array}$ & $\begin{array}{l}\text { На кінець } \\
2019 \text { року }\end{array}$ & $\begin{array}{c}2018 \\
\text { від } \\
2017\end{array}$ & $\begin{array}{c}2019 \text { від } \\
2018\end{array}$ \\
\hline \multirow{2}{*}{$\begin{array}{l}\text { 1. Коефіцієнт } \\
\text { поточної } \\
\text { ліквідності } \\
\text { (покриття) }\end{array}$} & $1195+1200$ & \multirow{2}{*}{$=2,0$} & \multirow{2}{*}{109} & \multirow{2}{*}{54,6} & \multirow{2}{*}{41,66} & \multirow{2}{*}{$-54,5$} & \multirow{2}{*}{$-12,94$} \\
\hline & 1695 & & & & & & \\
\hline \multirow{2}{*}{$\begin{array}{l}\text { 2. Коефіцієнт } \\
\text { швидкої } \\
\text { (критичної) } \\
\text { ліквідності }\end{array}$} & $\begin{array}{l}1195+1200- \\
-1100-1110 \\
\end{array}$ & \multirow{2}{*}{1,0} & \multirow{2}{*}{15,8} & \multirow{2}{*}{4,2} & \multirow{2}{*}{5,26} & \multirow{2}{*}{$-11,6$} & \multirow{2}{*}{1,06} \\
\hline & 1695 & & & & & & \\
\hline \multirow{2}{*}{$\begin{array}{l}\text { 3. Коефіцієнт } \\
\text { абсолютної } \\
\text { ліквідності }\end{array}$} & $1160+1165$ & \multirow{2}{*}{$\begin{array}{c}>0,2 \\
{[0,25 \ldots} \\
0,35]\end{array}$} & \multirow[t]{2}{*}{11} & \multirow[t]{2}{*}{2} & \multirow[t]{2}{*}{3,86} & \multirow[t]{2}{*}{$-9,01$} & \multirow[t]{2}{*}{1,86} \\
\hline & 1695 & & & & & & \\
\hline
\end{tabular}

*Складено авторами на підставі даних фінансової звітності підприємства АПК

3 табл. 7 видно, що коефіцієнти поточної і швидкої ліквідності впродовж усіх трьох років знаходяться в межах норми, що позитивно характеризує діяльність підприємства та свідчить про змогу підприємства покрити свої термінові зобов'язання та достатьою велічиною оборотних активів та такого їх елементу, як дебіторська заборгованість. Але негативним $є$ невідповідність коефіцієнту абсолютною ліквідності нормативному значенню, що свідчить про неможливість погашення підприємством його термінових зобов'язань абсолютно ліквідними активами - грошовими коштами та поточними інвестиціями, важливим елементом оборотних активів підприємства.

Висновки та перспективи подальших досліджень. Проведене дослідження теоретичних та практичних аспектів фінансового аналізу оборотних активів в сучасних умовах функціонування підпри- 
ємств, дозволило отримати певні результати і зробити висновки:

- в публікаціях вчених та практичних джерелах існує безліч підходів до виділення етапів проведення аналізу оборотних активів, але 3 точки зору більшості досліджень вчених ключовими етапами такого аналізу є аналіз складу, структури та динаміки активів, оборотних активів та їх елементів, джерел їх фінансування, оборотності оборотних активів та їх елементів, рентабельності оборотних активів та іiі факторного аналізу;

- дослідження деяких вчених підтверджує, що фінансовий аналіз оборотних активів необхідно починати 3 оцінки динаміки основних видів оборотних активів та оцінки їх ліквідності, але на нашу думку, важливим для управління активами, в які вкладено оборотний капітал підприємства, є питання вивчення, вимірювання, аналіз впливу факторів впливу на величину показників оборотних активів;

- наше попереднє дослідження показало, що одним з важливих етапів аналізу оборотних активів, є аналіз складу, структури та динаміки його важливих елементів, як грошові кошти, запаси та дебіторська заборгованість, які проаналізовано нами на підставі даних фінансової звітності підприємства АПК Одеської області за 2017-2019 роки та дозволяє проводити постійний моніторинг даних елементів в системі управління підприємством;

- дослідження публікацій вчених та практичних аспектів діяльності підприємств підтвердило, що важливими етапами аналізу оборотних активів, на нашу думку, $є$ й розрахунок в динаміці фінансового циклу підприємства й фінансовий аналіз відносних показників, які характеризують фінансову стійкість підприємства та ліквідність його балансу, що має особливе значення для ефективного функціонування підприємства, залучення інвестицій та розвитку діяльності, та для розрахунку яких використовують або показники оборотних активів та власних оборотних коштів (активів), або їх елементів, що розраховано нами на підставі даних підприємства АПК Одеської області;

- напрямами подальшого дослідження фінансового аналізу оборотних активів в системі управління підприємства $є$ оцінка впливу оборотності оборотних активів та їх елементів на ліквідність балансу підприємства, що дозволить більш ефективно впливати на фінансовий стан підприємства, який є важливим для розвитку діяльності підприємства та залучення інвесторів, сприяє забезпеченню ефективності його функціонування та конкурентоспроможності.

\section{Лiтература}

1. Купріна Н.М., Ступницька Т.М., Баранюк Х.О., Величко О.М. Оборотні активи в системі управління підприємства: сучасні аспекти обліку, аналізу та аудиту // Економіка харчової промисловості. 2021. Т. 13, вип. 2. C. 50-57. doi: 10.15673/fie.v13i2.2040 (дата звернення: 25.07.2021)

2. Антонюк О.П., Ступницька Т.М., Купріна Н.М. Економічний аналіз (практикум): навчальний посібник: 3-те вид. Львів: «Магнолія 2006», 2015. 326 с.

3. Сгорова О. В., Дорогань-Писаренко Л. О., Тютюнник Ю. М. Економічний аналіз: навч. посіб. Полтава : РВВД ПДАА, 2018. 290 с.

4. Павленко О.П., Бурсук Г.Ю. Фінансовий аналіз оборотних активів та оптимізація джерел їх формування // Молодий вчений. 2017. № 10(50) жовтень, С. 981-984.

5. Пріб К.А., Патика Н.І. Діагностика в системі управління: навч. посіб. К.: Центр учбової літератури, 2016. $432 \mathrm{c}$.

6. Савченко А.М., Матвіюк А.В. Оборотні активи виробничого підприємства в сучасних умовах: обліково-аналітичний аспект // Східна Європа: економіка, бізнес та управління. 2019. Вип. 6 (23). С. 698-705.

7. Бланк И.А. Финансовый менеджмент: учеб. курс. 2-е изд., перераб. и доп. К.: Ника-Центр, Эльга, 2007. $656 \mathrm{c}$.

8. Крамаренко Г.О. Фінансовий аналіз і планування. К.: Центр навчальної літератури, 2003. 224 с.

9. Мец В.О. Економічний аналіз фінансових результатів та фінансового стану підприємства: навч. посіб. К.: Вища школа., 2003. 278 с.

10. Мних С. В. , Барабаш Н. С. Фінансовий аналіз: навч. посіб. / Київ. нац. торг.-екон. ун-т. Київ : КНTEУ, 2010. 412 c.

11. Цал-Цалко Ю.С. Фінансовий аналіз: підруч. К.: ЦУЛ, 2008. 566 с.

12. Куприна Н.М. Совершенствование механизма управления оборотным капиталом в пищевой промышленности: дис. ... к.е.н.: 08.07.01: защита: 28.04.2006 / науч. рук. Бутенко А.И. Одесса: ИПРЭЭИ, 2006. $231 \mathrm{c}$.

13. Бланк И.А. Основы финансового менеджмента. К.: Ника-Центр, Эльга, 2001. Т.1: Серия «Библиотека финансового менеджера. 592 с. 


\author{
Kuprina $\mathbf{N}$. \\ Doctor of Economics, Associate Professor \\ Department of Accounting and Auditing \\ E-mail:k.natali_@ukr.net \\ ORCID ID: 0000-0003-4645-545X
}

\section{Antonyuk 0.}

Ph.D., Associate Professor

Department of Accounting and Auditing

E-mail: olegantoni@ukr.net

ORCID ID: 0000-0002-9182-4982

\author{
Stupnytska T. \\ Ph.D., Associate Professor \\ Department of Accounting and Auditing \\ E-mail: t.stupnitska@gmail.com \\ ORCID ID: 0000-0002-2517-2795
}

Velychko 0.

The student of the forth grade of Economy, Business and Control Faculty Odessa National

Odessa National Academy of Food Technologies

Kanatna str., 112, Odesa, Ukraine, 65039

E-mail: velichko20012001@gmail.com

ORCID ID: 0000-0002-8591-878X

\section{MODERN ASPECTS OF FINANCIAL ANALYSIS OF CURRENT ASSETS OF THE ENTERPRISE}

The effective functioning of any enterprise in modern conditions is not possible without effective management of its capital, which is invested in its current and non-current assets. Working capital must have a sufficient turnover rate and requires constant monitoring and analysis, which contributes to its effective use and management, and requires a qualitative financial analysis.

The article examines the theoretical and practical aspects of financial analysis of current assets in modern conditions of operation of enterprises. The study confirmed that in the publications of scientists and practical sources there are many approaches to the selection of stages of analysis of current assets, but from the point of view of most research scientists key stages of such analysis are analysis of the composition, structure and dynamics of assets, current assets and their elements sources of financing, turnover of current assets and their elements, profitability of current assets and its factor analysis. It has been substantiated that the financial analysis of current assets should begin with the assessment of the dynamics of the main types of current assets and their liquidity, but important for the management of assets in which the working capital is invested, is the question of study, measurement, analysis of factors influencing current assets.

It has been proved that a detailed analysis of important elements of current assets will allow constant monitoring of their condition, structure and dynamics, which will direct their effective management and prevent the diversion of working capital from the company's turnover and the process of normal financing of its activities. Therefore, important stages of analysis of current assets, in our opinion, are the calculation of the dynamics of the financial cycle of the enterprise and financial analysis of relative indicators that characterize the financial stability of the enterprise and its liquidity, which is especially important for efficient operation, investment and development and for the calculation of which they use either indicators of current assets and own current assets (assets), or their elements.

Key words: current assets, working capital, elements of current assets, enterprise, financial analysis, stages of financial analysis, efficiency of use.

\section{References}

1. Kuprina, N., Stupnytska, T., Baraniuk, Kh., \& Velychko, O. (2021). Current assets in the enterprise management system: modern aspects of accounting, analysis and audit. Food Industry Economics, 13(2), 50-57. doi: 10.15673/fie.v13i2.2040

2. Antonyuk, O. P., Stupnytska, T. M., \& Kuprina, N. M. (2015). Ekonomichnyi analiz (praktykum) (3rd ed.). «Mahnoliia 2006».

3. Yehorova, O. V., Dorohan-Pysarenko, L. O., \& Tiutiunnyk, Yu. M. (2018). Ekonomichnyi analiz. RVVD PDAA.

4. Pavlenko, O. P., \& Bursuk, H. Yu. (2017). Finansovyi analiz oborotnykh aktyviv ta optymizatsiia dzherel yikh formuvannia. Molodyi vchenyi, (10(50)), 981-984.

5. Prib, K. A., \& Patyka, N. I. (2016). Diahnostyka v systemi upravlinnia. Tsentr uchbovoi literatury.

6. Savchenko, A. M., \& Matviiuk, A. V. (2019). Oborotni aktyvy vyrobnychoho pidpryiemstva v suchasnykh umovakh: oblikovo-analitychnyi aspekt. Skhidna Yevropa: ekonomika, biznes ta upravlinnia, (6(23)), 698-705.

7. Blank, I. A. (2007). Finansovyiy menedzhment (2nd ed.). Nika-Tsentr, Elga.

8. Kramarenko, H. O. (2003). Finansovyi analiz i planuvannia. Tsentr navchalnoi literatury.

9. Mets, V. O. (2003). Ekonomichnyi analiz finansovykh rezultativ ta finansovoho stanu pidpryiemstva. Vyshcha shkola. 
10. Mnykh, Ye. V., Barabash, N. S. (2010). Finansovyi analiz.

11. Tsal-Tsalko, Yu. S. (2008). Finansovyi analiz. TsUL.

12. Kuprina, N. M. (2006). Sovershenstvovanie mehanizma upravleniya oborotnyim kapitalom $v$ pischevoy promyishlennosti (thesis: k.e.n.: 08.07.01; zaschita: 28.04.2006; nauch. ruk. Butenko A. I.) IPREEI.

13. Blank, I. A. (2001). Osnovyi finansovogo menedzhmenta (Vol. 1, Ser. Biblioteka finansovogo menedzhera). Nika-Tsentr, Elga.

Received 30 July 2021

Approved 13 August 2021

Available in Internet 24.10.2021

Цитування згідно ДСТУ 8302:2015

Купріна Н.М., Ступницька Т.М., Антонюк О.П., Величко О.М. Сучасні аспекти фінансового аналізу оборотних активів підприємства // Економіка харчової промисловості. 2021. Т. 13, вип. 3. С. 46-55. doi: 10.15673/fie.v13i3.2131

Cite as APA style citation

Kuprina, N., Stupnytska, T., Antonyuk, O., \& Velychko, O. (2021). Modern aspects of financial analysis of current assets of the enterprise. Food Industry Economics, 13(3), 46-55. doi: 10.15673/fie.v13i3.2131 